\title{
Comparative Historical Sociology and Transnational History: A Response to Julian Go's Patterns of Empire
}

\author{
Jonathan Hyslop \\ (Colgate University and University of Pretoria)
}

The idea that America is an exceptional and universally benevolent force in world history is one that is widely adhered to in American political culture and has influenced some strands of American historiography. In his book Patterns of Empire, sociologist Julian Go seeks to explode that myth. By comparing present American global power with the fallen British Empire, he attempts to show that they underwent a very similar pattern of development, and that both held to a delusionary belief in their own exceptionality. ${ }^{1}$ Both have exercised imperial power while often denying they were empires.

Go's argument, at its core, is a very elegant one. He suggests that the US and Britain followed the same path of imperial ascent, dominance, and decline. This course was run at different points in historical time. Go contends that the apparent difference between a British propensity for direct rule and American avoidance of colonial ownership of territory is not an important or real one. Both states at various times used techniques of formal and informal control. A range of modalities and techniques of empire were called upon on different occasions. And an important part of Go's argument is that at the phase of dominance, it is easier for the metropolis to hold back from military intervention, whereas in the moments of ascent and decline, there have been much stronger imperatives for the use of force.

In this response to the book, I want first of all to set out a few of my own ideas about the study of large scale historical change, especially as it bears on the study of major states and empires. My point of departure is the need to make a distinction between the method of comparative historical sociology, which I think Go's work represents, and contemporary developments in the writing of transnational history.

The great gain of recent transnational or global history has been that historians have started to overcome what Marcel van der Linden has called 'methodological nationalism'.2 Methodological nationalists naturalize the nation state, and conflate the social with the state and with the boundaries of a national territory. ${ }^{3}$ Much of modern historiography has assumed this 'normality' of the nationally organized state and nationalist politics. This has had important analytical and political consequences. Methodological nationalist history leads not only to a focus on nation-states as the organizing category of history, but also to the assumption that in the absence of a national state, aspirant nationalism will be the normal form of politics. Yet as we know, the nation state is a relatively recent invention; empires and city-states have been far more historically normative until the twentieth century. And assuming that the modern politics always consists of national groups 
striving for an independent state can be a highly misleading view. Many of the most important social and political movements of modernity have operated across national boundaries. Transnational history is history that is open to the possibility that national or imperial boundaries are not always the crucial definers of culture and politics. Taking a cue from Lyotard, one might say that the practice of transnational history can be defined as incredulity toward national and nationalist narratives.

Go's work is a stimulating return to the practice of large scale comparative historical sociology, an approach which has a long and honorable tradition in the social sciences. But the project of comparative historical sociology is a clearly different one from that of writing transnational history. That is not to say that one of these methods is inherently inferior to the other: both can and have produced very fine and valuable work. But they are not the same thing.

Barrington Moore's Social Origins of Dictatorship and Democracy, published in 1966, is perhaps the classic exemplar of comparative historical sociology, with its massive examination of the similarities and differences that determined the evolutionary paths of major states. ${ }^{4}$ In the 1970 s and into the1980s, it seemed as if such comparative work might assume a central place in sociology and historiography. Theda Skocpol's States and Social Revolutions came out in 1979 to enormous acclaim. 1982 saw the posthumous publication of Philip Abrams' great (though sadly neglected) book Historical Sociology, which argued for the inseparability of the historical and sociological enterprises, and in 1988 there was the establishment of the innovative Journal of Historical Sociology. ${ }^{6}$ By no means all the work in this field was comparative, but its practitioners were consistently interested in comparative questions.

However, in the subsequent period, comparative historical sociology failed to flourish to the extent that one might have expected. This happened partly because of the intellectual shift to poststructuralist and culturalist concerns amongst scholars. A hostile environment for the pre-occupations of historical sociologists developed. And indeed there were valid grounds to criticize the tendency of historical sociology to fall into overly structural modes of explanation, which left little scope for contingency or cultural and ideological factors. Thus Skocpol's work, for example, accounted for revolution in major states by the imbalance between, on the one hand, the military challenges of the external world and on the other, the internal problems of class relations and the raising of revenue. In this approach, actors had very limited scope for agency. Ideas play a very minimal part in her analysis. Revolutionaries did not overthrow states, but occupied the space left when states fell apart.

When, much later, scholars turned their attention back to large scale problems, it was under the banner of transnational or global history. The new work has been very different from comparative historical sociology, for it stresses not making the contrasts between discrete political units, but the centrality of linkages between 
social and political processes across state boundaries. Networks are treated as central, and the long geographical reach of social and political movements receives great attention, as do transoceanic 'flows' of people, goods and ideas. While some writers move easily between the terms 'comparative history' and 'transnational history', they clearly involve very different ways of studying empire.

Empires, I would argue, are based on multiple forms of power. Here I follow the analytical framework of Michael Mann. ${ }^{7}$ Mann understands social organization as constituted from overlapping and intersecting power networks. These networks are ideological, economic, military and political. None of these levels is necessarily predominant over the others, but one or more might be so in a particular social formation. Mann insists that we view power sources as networks, because he distrusts any notion of dynamics or logics of organization that are taken to have a life of their own, distinct from the people who comprise them. Now Mann does make large scale comparisons of different countries. But importantly for the study of empires, he insists that power sources / networks do not add up to 'a society' in the conventional sense, because such networks do not necessarily or even usually coincide with political boundaries - or by implication, with the boundaries of a given empire. There is thus a good fit between his method and the thinking of transnational historians.

Logically, comparative historical sociology requires three things for its effective execution. There must be clear criteria of comparison. These categories must be operationalized through effective and coherent methods of quantitative measurement or qualitative assessment. And the objects of analysis - the sociopolitical units to be analyzed - must be clearly differentiated and defined.

The adoption of transnational modes of thinking about history makes these tasks more difficult, by shaking up our understanding of the stability of the units to be analyzed. Contemporary developments in global history question the apparently unproblematic political boundaries which up to now have tended to be taken for granted. For example, from a transnational perspective, simply drawing the line between the British and American empires is more complex than it appears. Consider the issues raised by James Belich's remarkable survey of settler colonial societies, Replenishing the Earth. ${ }^{8}$ Belich points out that contrary to what one might have expected, after the War of 1812, there was a massive British infusion of capital and people into the United States, which, with fluctuations, lasted for most of the rest of the century. A British 'recolonial' connection largely funded and drove the expansion of the US into the west of the North American continent. In other words, the conquest and colonization of 'The West' was inconceivable without the funding provided by the City of London, the immigrants from the United Kingdom, and the skills they brought with them. During the first half of the nineteenth century the economies of the two empires became massively intertwined, more so than in the time when America was a British colony, with the US by about 1850 sending half its exports to Britain and receiving $40 \%$ of Britain's total exports in return. The conquest of Native Americans and Mexicans, in Belich's view, not only paralleled the 
rise of the settler colonies of Canada, Australasia and southern Africa, which were also creating 'Wests' of their own, but was materially linked to those events via London, Liverpool and Glasgow. Moreover, at the time, the elite of the US was to a large degree under the cultural hegemony of Britain. So in Belich's telling, distinctions between Britain and the US as socio-political units remained extremely porous down to $1900 .{ }^{9}$

Having registered these methodological concerns about comparativism, I now want to make two substantive points about the history of imperialism and antiimperialism affect my evaluation of Go.

Firstly, metropolitan politics in any imperial state is inextricable from the politics of the periphery. One of the most puzzling aspects of recent scholarship on British imperialism is the following which has been gathered by Bernard Porter's view that the British people were largely uninterested in their empire, a position which tends to minimize the role of imperial politics in the metropolis. ${ }^{10}$ Yet this is a highly contestable position. John MacKenzie and his school have produced massive documentation of the way that imperial culture permeated every aspect of British life. ${ }^{11}$ And it is inherently implausible that in nineteenth and early twentieth century, with massive family connections to the empire through emigration, the return of up to a quarter of all emigrants from abroad, and enormous numbers of working class people employed around the world in the army, the merchant navy and as artisans, the empire was somehow outside British popular political consciousness. From the loss of the American colonies through the Boer War to the Suez Crisis, imperial matters were often central to British politics. Moreover, the politics of component sections of an imperial state are often linked to imperial politics. In recent decades our understanding of the British polity which have been remade by the development of a 'Four Nations' perspective. This work has shown that Ireland, Wales and Scotland all had their own complex relationships to the empire, to each other, and to England. ${ }^{12}$

It is probably the case that politics and popular culture in the US has been less orientated to questions of international power than in Britain. Perry Anderson has recently shown how American foreign policy politics plays out within a fairly small political circle. ${ }^{13}$ But even there, as Anderson argues, the direction of that policy is highly contested because of the possibilities that political activists have for influencing an executive which is fairly autonomous of the legislature in the external sphere. Consider a major recent major contribution to historical sociology, Ira Katznelson's Fear Itself. ${ }^{14}$ In his investigation of how the South shaped the development of US power in the 1930s and 1940s, Katznelson details how Roosevelt's reshaping of the American social order and global role, and the establishment of peace time US world dominance under Truman, were crucially affected by these leaders' management of the internal forces of the American polity. Emphasizing the seriousness the threat of fascist political influence in American politics, Katznelson shows especially how southern support was crucial to the ability of the New Dealers to oppose Germany and to make internal reforms, albeit 
at the price of conceding the continuation of racial segregation and attenuating the radicalism of some of the new social policies. This configuration, in Katznelson's view, formed the contours of post-1945 American world power. Katznelson's work demonstrates the importance of understanding metropolitan battles in imperial politics.

Secondly, we should not assume that anti-colonial nationalism was a normative, universally present and pervasive force throughout the colonial period. To do so is a product of methodological nationalism. It is undoubtedly the case that one of the great gains of historiography in the post colonial period has been the new emphasis on the actions of the colonized. But the rise of anti-colonial nationalism happened at a very uneven pace. Much political agitation within colonized elites up to the early twentieth century was aimed at obtaining a better deal within the empires rather than overthrowing them. For example Gandhi, who led significant Indian protest movements in South Africa between 1908 and 1913, never called unambiguously for Indian independence until well after he returned to India in $1915 .{ }^{15}$ As Mark Mazower has demonstrated, at the end of the Second World War, none of the great powers, including the USSR, foresaw the strong political impact that the non-aligned former colonial countries would have in the UN. ${ }^{16}$ For the European powers, in 1945 anti-colonial nationalism did not seem unmanageable. In Britain, while the post-war Labour government were reconciled to abandoning Palestine and giving up India, they did not envisage withdrawal from the rest of the empire, right up to the time they fell from office in 1951.

With these points in mind, I now want to turn to an assessment of Go's work.

Perhaps the first thing to say is that as a non-American, I suspect that the issue of American exceptionalism is perhaps not as compelling for foreigners as it is to many citizens of the Republic. I understand why Go thinks it important to address the question. But to an outsider the idea that America is a uniquely virtuous power and somehow exempt from the constraints which act on other polities is likely to seem inherently implausible. It is perhaps noteworthy here that even American power's most enthusiastic foreign-born intellectual supporter, Niall Ferguson, does not dispute that America is an Empire like Britain: he just wants the US to embrace this role and emulate the Brits, to do a better job of it. So while I am sympathetic to the political value of debunking American exceptionalism, at the end of this exercise, those of us who were in any case disinclined to believe in it are not left any further forward.

Le us consider then how well Go's work meets the need for clear categories, measures and objects of analysis.

Does Go establish a satisfactory understanding of the fundamental category of 'Empire' ? Go's framework is one of comparing national states plus their global extensions with one another. Go defines an Empire as "a sociopolitical formation wherein a central political authority (a king, a metropole, or an imperial state) 
exercised unequal influence and power over the political (and in effect the sociopolitical) process of a subordinate society, peoples (sic) or space". ${ }^{17}$ A major empirical problem with this definition is Go's insistence that economic power cannot constitute an empire: a state actor is required. Yet in reality private companies have played an enormous role in constituting empires, particularly in the form of the Dutch East and West India Companies and the British East India Company. Even in the late nineteenth century, Belgium's Congo company, the Royal Niger Company and the British South Africa Company, all established the basis of what were to become major states. ${ }^{18}$ Go's attempts to play down the importance of the British East India Company are somewhat unconvincing, given that there was a century long struggle by the British government to bring it under control. Imperial forms of power were in fact diverse, as Mann's approach would suggest.

Go places a great deal of reliance on the category of imperial 'decline'. He uses an exclusively economic criterion here; when a state ceases to be the dominant economic power in the world it is in a state of decline. But this is not satisfactory, if, as I have argued, we need to see imperial power as being exercised in multiple forms. Britain indeed had a smaller manufacturing sector than the US and Germany by the start of the $20^{\text {th }}$ century. But that had not translated into any real diminution of the absolute dominance of the City of London over the world's financial markets. Britain was master of world shipping, and thus of global trade. The Royal Navy still controlled the world's seas and by 1914 Britain was winning the naval arms race with Germany. The First World War, not slipping industrial competiveness, dislodged the United Kingdom from its central position of global power. Similarly, it is perfectly true that China is now responsible for a bigger proportion of world manufacturing than America. But the huge industrial dominance that the US had in 1945 was an artifact of a singular historical moment. The industry of all the other great powers had been destroyed, or at the very least severely damaged, by war. As they re-built, it was inevitable that America's proportion of the world economy would fall. The US today is not self-evidently down and out. Its military machine is unrivalled by any other power or group of powers; American cultural hegemony in the world is still extraordinary; the US exercises de facto or de jure veto powers over many forms of intergovernmental organization. Much manufacturing that does take place in China and elsewhere happens under the aegis of American transnational corporations. It is certainly possible to make a case for the decline of American power, but it would need to be done on a broader basis than that which Go gives us.

Go makes a strong claim for the correlation between imperial hegemony and relatively peaceful use of power on the one hand, and imperial decline and an increase in military aggression on the other. It is by no means clear why the American role in Vietnam - a war which took place in what Go sees as the era of American dominance - should count less as an indicator of aggressiveness than the wars in Afghanistan and Iraq, which are supposed to be manifestations of increased militarism in the age of US decline. Go's way of assessing aggression- by counting the number of external military interventions - seems questionable. He provides a superficially convincing graph showing that the number of American military 
interventions since the early 1970s increased relative to the previous period, but that is not the only possible way to measure pugnacity. One might, for example, take willingness to accept casualties as an indicator of militarism. On this measure we get a very different picture, with the American military fatalities of 1945-1973, at about 100000 , dwarfing those of the period since 1973, at about 7 000. And the procedure does seem to lead to some odd conclusions: the Cape Frontier Wars, the Sikh Wars, the Opium Wars, the Crimean War and the repression of the Indian 'Mutiny' can surely only with some difficulty be seen as part of an era characterized by pacifically-inclined British dominance.

One could also query whether Go's primarily political definition of what an empire is, is compatible with using a primarily economic criterion to determine imperial decline. Adopting a more multiple approach to forms of imperial power might help to avoid such apparent inconsistency.

What about the objects of Go's analysis? As indicated above, the histories of the US and Britain as imperial entities in the nineteenth century are harder to disentangle than one might think. Belich characterizes the US and the British Empire in that period as "a politically and geographically divided but economically and culturally united entity capable of enhanced cross-insemination". ${ }^{19}$ If this is so, to separate out the two empires for analysis is a tricky exercise.

There is a tendency in Go's book to give an account of imperial policy which does not sufficiently acknowledge the divergences and disunities within the metropolis which have important consequences for the choice of imperial policies. I don't put it more strongly than to say this is a tendency, because at some points Go does recognize some of the complexities of this politics. But he does see great powers as acting from their interests, and for Go what determines those interests is primarily the position of the core state in the world system.

In this respect, Go follows the propensity already noted in some historical sociology toward an overly structural mode of interpretation. In reality, interests are never self-evident to actors: they are constituted through discourse. Leaders, parties and classes in the metropolis fought long and hard over imperial policy. To recognize the importance of anti-colonial resistance, as Go rightly wishes to do, does not necessitate treating metropolitan politics as a simply a mechanism responding to structural changes in the world political order. Political struggles in the metropolis were often crucial for the colonized world. For instance, had the Conservatives won the 1945 British election, it is hard to imagine that a Churchill government would have surrendered India without at fight as the Attlee government did. ${ }^{20}$ Undoubtedly independence would still have come to India in the long run, but the path to it would have been very different and left a differently shaped subcontinent.

Political beliefs at the center do matter. And this takes us back to the question of exceptionalism. One can recognize that exceptionalism is an ideology without denying that that ideology had real effects. It would be extraordinary if, as Go seems 
to suggest, American politicians constantly spouted exceptionalist rhetoric, but in virtually every case, were then able to put it aside when it came to action, pursuing the goals of a pure realpolitik. The case of the American attitude to territorial colonialism before, during and after World War II is a case in point. It was in fact perfectly possible for US policy makers to believe genuinely in the iniquity of British colonialism, and not to desire to replicate it, while seeking to build their own global dominance. Thus for example, in the mind of Franklin Roosevelt, the ideal of selfgovernment in India (over which he clashed with an enraged Churchill) was perfectly compatible with the desirability of US domination of world markets. In the liberal framework of FDR's thinking, it was possible to imagine the role of future national legislatures of newly independent countries as providing real national control of political administration but also as being friendly to the 'rights' of American capital to operate freely and to the positioning of American bases on their territory. ${ }^{21}$

Finally, I would suggest that Go's emphasis on the pervasive strength of anti-colonial nationalism is perhaps exaggerated. Take the field of African history for example.

Go's desire to criticize Eurocentric histories of imperialism is commendable, but, at least for this body of work, there is a danger of flogging a dead horse. A historiography which seeks to challenge Eurocentrism has been at work for decades. ${ }^{22}$ Yet it is not the case that the resulting work has produced a picture of a sub-Saharan Africa uniformly and universally driven by nationalist politics. The resistance of the late nineteenth and early twentieth centuries sought to preserve pre-colonial states, not to create modernist nations. Resistance to colonial domination was present throughout the modern era but it was often in informal and muted forms, and expressed through sectional, class and religious identities. Most African modernist political groupings up to the Second World War were elite movements seeking a better accommodation with the colonial power. It was only in the 1940s that mass nationalist movements emerged. But by 1945 the colonial powers were still able to feel that they could realistically envisage, at the very least, decades more of colonial rule. It was in the 1950s that African nationalism and international pressures became powerful enough for the major colonial powers to come to the conclusion they had to grant African independence in the short term. Even then, the weak Portuguese state managed to hang on to its colonies until 1974, and the Rhodesian settlers to stay in power until 1980. This does at least raise questions over Go's argument that the strength of twentieth century anticolonialism was such that it explains why the US refrained from direct colonial intervention.

The danger of a comparative method which simply contrasts empires that were contemporaneous with each other is that it ignores the possibility that they were crucially entangled together. An approach which plays down the role of discourse and agency can lead us to an excessively deterministic view of the course of empires. And seeing the politics of metropolis and colony as always in Manichean confrontation runs the risk of missing how their politics interpenetrated. A transnational mode of historical analysis, linked to a suspicion toward overly 
structuralist modes of explanation, an awareness of the multiple forms of power, and a sensitivity to the ambivalent complexity of politics, may enable us to avoid those mistakes.

1 Julian Go, Patterns of Empire: The British and American Empires, 1688 to the Present (New York: Cambridge University Press, 2011).

2 Marcel van der Linden, "Labour History: The Old, the New and the Global", African Studies, Aug-December 66:2/3, 2007, 169-180.

3 Van der Linden, "Labour History", 74.

${ }^{4}$ Barrington Moore Jr., Social Origins of Dictatorship and Democracy (Boston:

Beacon Press, 1966).

5 Theda Skocpol, States and Revolutions: A Comparative Analysis of France, Russia and China (Cambridge, Cambridge University Press, 1979).

6 Philip Abrams, Historical Sociology (Shepton Mallet: Open Books, 1982).

7 Michael Mann, The Sources of Social Power volumes 1-4 (Cambridge: Cambridge University Press, 1986-2012).

8 James Belich, Replenishing the Earth: The Settler Revolution and the Rise of the Angloworld 1783-1939 (Oxford: Oxford University Press, 2009).

${ }_{9}^{9}$ And one might argue that from the First World War, Britain was again enmeshed with American power, but now the terms were reversed. The United Kingdom, saddled with the massive war debts of the conflict was increasingly subordinated to the power of American bankers. And of course by 1941 Britain effectively became the military client of the United States. From the start of cinema and recorded music, Britain increasingly came under US cultural domination. From a transnationalist perspective, it is very hard to make the sort of contrast that Go does between a clearly separated 'America' and 'Britain' in the twentieth Century as well as the nineteenth.

10 Bernard Porter, The Absent Minded Imperialists: Empire, Society and Culture in Britain (Oxford: Oxford University Press, 2004).

11 See the approximately one hundred volumes in the Manchester University Press Studies in Imperialism series edited by MacKenzie; a good starting point is John MacKenzie, Propaganda and Empire: The Manipulation of British Public Opinion 1880-1960 (Manchester: Manchester University Press, 1988).

12 See for example Christopher Harvie, A Floating Commonwealth: Politics, Culture and Technology on Britain's West Coast 1860-1930 (Oxford: Oxford University Press, 2012).

13 Perry Anderson, “American Foreign Policy and Its Thinkers: Consilium”, New Left Review, 83, 2013, 113-167.

14 Ira Katznelson, Fear Itself: The New Deal and the Origins of Our Time (New York: Liveright, 2013).

15 In my analysis of Gandhi's key text of the pre-First World War period, I demonstrate the studied ambiguity of his attitude toward the idea of Indian independence; see Jonathan Hyslop, “An 'Eventful' History of Hind Swaraj: Gandhi Between the Battle of Tsushima and the Union of South Africa", Public Culture, 23:2, 2011, 299-319. 
16 Mark Mazower, No Enchanted Palace: The End of Empire and the Ideological Origins of the United Nations (Princeton, Princeton University Press, 2009).

17 Go, Patterns, 7.

18 The forthcoming work of Ed Cavanagh will make an important contribution on this question. Ed Cavanagh, "How Companies Got Their Land and the Natives Lost It: The Corporate Foundations of Settler Colonialism in the USA and South Africa", Lecture at Colgate University, 2013:

http://www.youtube.com/watch?v=Uj4fhSF2IqU

19 Belich, Replenishing the Earth, 144.

20 Neil Smith, American Empire: Roosevelt's Geographer and the Prelude to Globalization (Berkeley, University of California, 2003).

${ }^{21}$ Peter Clarke, The Last Thousand Days of the British Empire: Churchill, Roosevelt and the Birth of the Pax Americana (New York: Bloomsbury, 2008).

22 For a fine and up to date survey of the field, see John Parker and Richard Rathbone, African History: A Very Short Introduction (Oxford: Oxford University Press, 2008).

Abrams, Philip. Historical Sociology (Shepton Mallet, Open Books, 1982).

Anderson, Perry. "American Foreign Policy and Its Thinkers: Consilium”, New Left Review, 83, 2013, 113-167.

Belich, James. Replenishing the Earth: The Settler Revolution and the Rise of the Angloworld 1783-1939 (Oxford: Oxford University Press, 2009).

Cavanagh, Ed. "How Companies Got Their Land and the Natives Lost It: The Corporate Foundations of Settler Colonialism in the USA and South Africa", Lecture at Colgate University, 2013: http://www.youtube.com/watch?v=Uj4fhSF2IqU

Clarke, Peter. The Last Thousand Days of the British Empire: Churchill, Roosevelt and the Birth of the Pax Americana (New York: Bloomsbury, 2008).

Go, Julian. Patterns of Empire: The British and American Empires, 1688 to the Present (New York: Cambridge University Press, 2011).

Harvie, Christopher. A Floating Commonwealth: Politics, Culture and Technology on Britain's West Coast 1860-1930 (Oxford: Oxford University Press, 2012).

Hyslop, Jonathan. An 'Eventful' History of Hind Swaraj: Gandhi Between the Battle of Tsushima and the Union of South Africa", Public Culture, 23:2, 2011, 299-319.

Katznelson, Ira. Fear Itself: The New Deal and the Origins of Our Time (New York: Liveright, 2013) 
MacKenzie, John. Propaganda and Empire: The Manipulation of British Public Opinion 1880-1960 (Manchester: Manchester University Press, 1988).

Mann, Michael. The Sources of Social Power volumes 1-4 (Cambridge: Cambridge University Press, 1986-2012).

Mazower, Mark. No Enchanted Palace: The End of Empire and the Ideological Origins of the United Nations (Princeton, Princeton University Press, 2009).

Moore Jr., Barrington. Social Origins of Dictatorship and Democracy (Boston: Beacon Press, 1966).

Parker, John and Rathbone, Richard. African History: A Very Short Introduction (Oxford: Oxford University Press, 2008).

Porter, Bernard. The Absent Minded Imperialists: Empire, Society and Culture in Britain (Oxford: Oxford University Press, 2004).

Skocpol, Theda. States and Revolutions: A Comparative Analysis of France, Russia and China (Cambridge: Cambridge University Press, 1979).

Smith, Neil. American Empire: Roosevelt's Geographer and the Prelude to Globalization (Berkeley, University of California, 2003).

Van der Linden, Marcel. "Labour History: The Old, the New and the Global", African Studies, Aug-December 66 2/3, 2007, 169-180. 